\title{
Sławomir Zwolak
}

Katolicki Uniwersytet Lubelski Jana Pawła II

sla_z@poczta.fm

\section{Wartości jako przedmiot ochrony policji budowlanej}

\section{Values as the Object of Protection of the Construction Police}

\section{STRESZCZENIE}

Niniejsze opracowanie dotyczy ochrony podstawowych wartości, takich jak bezpieczeństwo, porządek publiczny i ład architektoniczno-przestrzenny. Wartości te można dostrzec już przez pryzmat ograniczeń wolności budowlanej. Ich ochrona jest szczególnie cenna dla społeczeństwa i stanowi jedną z właściwości przypisywanych policji budowlanej. Doniosłą rolę w tym zakresie powierza się jej jako instytucji związanej z ustaleniem i przeciwdziałaniem zagrożeniom naruszającym ogólne bezpieczeństwo i ład w budownictwie.

Słowa kluczowe: prawo budowlane; policja budowlana; bezpieczeństwo i porządek publiczny; ład architektoniczno-przestrzenny

Z punktu widzenia społecznego czy aksjologicznego przyjmuje się, że wartości są usytuowane wewnątrz określonych społeczności, uznających je za własne i godne urzeczywistnienia ${ }^{1}$. Jak wskazuje S. Fundowicz, wartości mają charakter niezmienny, stanowią trwały i pewny układ odniesienia, na podstawie którego ludzkość tworzy kulturę, w tym prawo². Prawo jest strukturą normatywną funkcjonującą w rzeczywistości społecznej, której elementem są owe wartości. Biorąc pod uwagę prawo administracyjne, a w szczególności przynależące do zakresu prawa administracyjnego prawo budowlane, należy stwierdzić, że przedmiot

\footnotetext{
${ }^{1}$ M. Miemiec, Wartości jako przedmiot ochrony w policyjnym prawie administracyjnym, [w:] Wartości w prawie administracyjnym. V Krakowsko-Wrocławskie Spotkanie Naukowe Administratywistów, red. J. Zimmermann, Warszawa 2015, s. 294.

${ }^{2}$ S. Fundowicz, Aksjologia prawa administracyjnego, [w:] Koncepcja systemu prawa administracyjnego. Zjazd Katedr Prawa Administracyjnego i Postepowania Administracyjnego, Zakopane 24-27 września 2006 r., red. J. Zimmermann, Warszawa 2007, s. 636.
} 
ochrony wartości jest jakby dwoisty ${ }^{3}$. Chroni się pewne dobra (jak życie, zdrowie i mienie) oraz pewne stany (bezpieczeństwo i porządek publiczny). Mimo że nierzadko wartości te występują jako nierozdzielne, uchwytna w ich ochronie różnica obrazuje różne nasilenie interesu publicznego, różny zasięg i znaczenie zagrożeń płynących dla tych wartości, znaczenie wyróżnionych stanów zasad współżycia społecznego, norm moralnych czy obyczajowych i złączonych z tym oceniających wypowiedzi organów ochronnych opartych zazwyczaj na normach uznaniowych, a także refleksy utrudnień w ochronie procesowej opartej na takich normach ${ }^{4}$. Z przywołanego stanowiska wartościami są więc wskazane dobra i stany chronione przez normy prawne.

Ustawa z dnia 7 lipca 1994 r. - Prawo budowlane ${ }^{5}$ chroni dobra i stany nazwane wartościami w obszarze prawa policyjnego. Pobieżny przegląd prawa budowlanego wskazuje, że prawodawca wiąże jego stosowanie z określonymi wartościami. Przede wszystkim potwierdza to zawarta w art. 4 pr. bud. zasada wolności budowlanej jako naczelna zasada prawa budowlanego, która nierzadko doznaje ograniczeń ze względu na wartości chronione. Znaczenie tej zasady dla jednostki jest oczywiste, gdyż służy ona ochronie podmiotów zaangażowanych w procesy budowlane ${ }^{6}$. W literaturze podnosi się, że wolność budowlana jest nie tylko zasadą prawa, ale także publicznym prawem podmiotowym o charakterze wolnościowym. Wolność budowlana stanowi element składowy konstytucyjnego prawa podmiotowego jako prawa własności ${ }^{7}$. Mając na uwadze stanowisko doktryny prawa mówiące o tym, że istota zasady wolności budowlanej wynika z potrzeby zapewnienia konstytucyjnej ochrony prawa własności ${ }^{8}$, należy przyjąć, że

${ }^{3}$ M. Miemiec, op. cit., s. 294. Należy podkreślić, że państwo prawa jest oparte na wartościach moralnych, gdyż honoruje uniwersalne wartości ludzkie. Można stwierdzić, że prawo administracyjne i administracja publiczna, które są powołane do zapewnienia porządku i ładu publicznego, za najwyższe wartości uznają wartości moralne. Zob. K. Kalinka, Relacje grup nacisku z administracja publiczna jako swoista wartość w prawie administracyjnym, [w:] Wartości w prawie administracyjnym..., s. 218.

${ }^{4}$ J. Boć, [w:] Prawo administracyjne, red. J. Boć, Wrocław 2004, s. 362.

${ }^{5}$ T.j. Dz.U. z 2016 r., poz. 290., dalej jako: pr. bud.

${ }^{6}$ Z. Leoński, Zasada wolności budowlanej i jej administracyjnoprawne ograniczenia, [w:] Rola materialnego prawa administracyjnego a ochrona praw jednostki, red. Z. Leoński, Poznań 1998, s. 141.

${ }^{7}$ R. Hauser, Z. Niewiadomski, Konstytucyjne aspekty regulacji procesu inwestycyjno-budowlanego, „Państwo i Prawo” 2015, z. 6, s. 3.

${ }^{8}$ Z. Leoński, Zasada wolności budowlanej i jej administracyjnoprawne ograniczenia [w:] Kierunki rozwoju prawa administracyjnego. Podstawowe zagadnienia prawa budowlanego i planowania przestrzennego. Dziesiąte niemiecko-polskie kolokwium prawników administratywistów. Poznań 8-12 września 1997 r. Referaty i głosy w dyskusji, red. H. Bauer, R. Hendler, P.M. Huber, B. Popowska, T. Rabska, M. Szewczyk, Poznań 1999, s. 362; idem, Materialne prawo administracyjne, Warszawa 2005, s. 120; idem, Zasada wolności budowlanej i jej administracyjnoprawne ograniczenia, [w:] Rola materialnego prawa administracyjnego ..., s. 141; W. Jakimowicz, Konstrukcja i istota wolnościowego prawa do zabudowy, „Samorząd Terytorialny” 2005, nr 6, s. 47. 
treścią zasady wolności budowlanej jest prawny nakaz poszanowania wolności i własności oraz uznać, że przepisy prawa budowlanego ograniczają potencjalny zakres inwestora wynikający z wolności budowlanej i prawa własności 9 .

Ograniczenie wolności budowlanej może wynikać z działań o charakterze policyjnym, ujętych w normach prawa budowlanego jako nakazy i zakazy. Działania te kładą nacisk na zakres przedmiotowy ingerencji właściwych organów, które odnoszą się do konkretnego zachowania podmiotów dotyczących faktycznych działań lub zaniechań i ich rezultatów, które mają odzwierciedlenie w poprawności utrzymania obiektów w należytym stanie technicznym ${ }^{10}$. Niektóre ograniczenia wolności budowlanej wykazują tendencje do stałego rozszerzania się i wzmacniania, natomiast inne, zmienne w treści, utrzymują się jako pewne trwałe zjawiska w strukturze prawa budowlanego w postaci nakazów, zakazów, pozwoleń czy różnorodnego nadzoru budowlanego. Ograniczenia te są wyrazem potrzeb społecznych zmierzających do zapewnienia bezpieczeństwa, ochrony zdrowia i mienia jednostek ${ }^{11}$.

Granice wolności budowlanej, chociaż wyznaczone na drodze ustawowej, są określone w Konstytucji RP. Zgodnie z art. 31 ust. 3 Konstytucji RP ${ }^{12}$ ograniczenia w zakresie korzystania z konstytucyjnych wolności i praw mogą być ustanawiane tylko w ustawie i tylko wtedy, gdy są konieczne w demokratycznym państwie dla jego bezpieczeństwa lub porządku publicznego bądź ochrony środowiska, zdrowia i praw innych osób i nie mogą naruszać istoty wolności i praw. Z kolei z treści art. 64 i 21 Konstytucji RP wynika, że wolność budowlana może być ograniczona tylko w drodze ustawy i tylko w zakresie, w jakim nie narusza ona istoty tego prawa, a ingerencja jest dopuszczalna jedynie wówczas, gdy jest dokonywana na cele publiczne.

Ingerencja w celu ochrony wartości jest przedmiotem policji administracyjnej. Określenie policji administracyjnej jako sfery ingerencji administracji oznacza, że sfera ta obejmuje swym działaniem ochronę bezpieczeństwa, porządku, spokoju publicznego, a zwłaszcza życia, zdrowia i mienia. Rolą policji jest zatem zagwarantowanie nienaruszalności dotychczasowego porządku, mienia i niektórych poddanych ochronie administracyjnoprawnej dóbr osobistych człowieka $^{13}$, a także kontrola przestrzegania normatywów policyjnych oraz sankcjo-

${ }^{9}$ Z. Leoński, M. Szewczyk, M. Kruś, Prawo zagospodarowania przestrzeni, Warszawa 2012, s. 252 .

${ }^{10}$ Zob. K. Zamyślewska-Gorząch, Wolność budowlana i jej prawne ograniczenia, „Samorząd Terytorialny" 2005, nr 10, s. 60-61.

${ }^{11}$ Zob. M. Wyrzykowski, Legislacja - demokratyczne państwo prawa-radykalne reformy polityczne i gospodarcze, [w:] Tworzenie prawa $w$ demokratycznym państwie prawnym, red. $\mathrm{H}$. Suchocka, Warszawa 1992, s. 45.

${ }^{12}$ Konstytucja Rzeczypospolitej Polskiej z dnia 2 kwietnia 1997 r. (Dz.U. nr 78, poz. 483 ze sprost. i późn. zm.).

${ }^{13}$ Zob. J. Boć, op. cit., s. 362-363. 
nowanie obowiązków z nich wynikających ${ }^{14}$. W obszarze prawa budowlanego policja jest określona przez strukturę organów wykonujących działania związane z utrzymaniem bezpieczeństwa, porządku publicznego, ochroną zdrowia i życia ludzkiego ${ }^{15}$. Kompetencje $\mathrm{w}$ tym zakresie mają nie tylko organy nadzoru budowlanego, ale również organy wchodzące w strukturę administracji architektoniczno-budowlanej. Powyższe organy administracji publicznej, stojące na straży bezpieczeństwa i porządku publicznego, są określane pojęciem policji budowlanej jako wyspecjalizowanej służby z zakresu regulacji budowlanych ${ }^{16}$.

Funkcja policji budowlanej jest nastawiona na urzeczywistnianie dobra publicznego, przeciwdziałając zjawiskom niebezpiecznym, które mając charakter publiczny, wpływałyby ujemnie na warunki życia zbiorowego ${ }^{17}$. Istotne kompetencje policji budowlanej dotyczą nadzoru budowlanego oddziałującego na procesy budowy i utrzymania obiektów budowlanych i przejawiają się w decyzjach dotyczących zapobiegania powstawaniu niebezpieczeństwa dla życia, zdrowia i mienia oraz porządku publicznego. Podstawowe znaczenie będą miały przede wszystkim: pozwolenie na budowę warunkujące rozpoczęcie robót budowlanych, pozwolenie na użytkowanie obiektu budowlanego zezwalające na użytkowanie obiektów oraz uprawnienia do wydawania nakazów i zakazów w toku użytkowania obiektów budowlanych ${ }^{18}$.

Policyjny charakter prawa budowlanego pozwala zauważyć, że podstawowym kierunkiem działania policji budowlanej jest utrzymywanie ładu architektoniczno-przestrzennego oraz zapewnienie bezpieczeństwa i porządku prawnego w budownictwie. Jak wcześniej wspomniano, cel ten jest realizowany w głównej mierze przy pomocy organów nadzoru budowlanego Przepisy prawa budowlanego dotyczące nadzoru budowlanego zawierają z reguły nakazy i zakazy typu policyjnego, podyktowane interesem ogólnym, a zwłaszcza wprowadzeniem ładu, porządku i bezpieczeństwa.

Bezpieczeństwo nie jest abstrakcyjnym pojęciem nauki prawa administracyjnego, gdyż prawo określa niektóre desygnaty tego pojęcia. Bezpieczeństwo jest podstawowym zadaniem władzy publicznej, ściśle związanym z jego funkcją.

${ }^{14}$ J. Dobkowski, Policja administracyjna. Zagadnienia doktrynalno-instytucjonalne, „Samorząd Terytorialny" 2004, nr 7-8, s. 17-18.

${ }^{15} \mathrm{~A}$. Chajbowicz, O podmiotowym znaczeniu pojęcia policja administracyjna, [w:] Nowe problemy badawcze w teorii prawa administracyjnego, red. J. Boć, A. Chajbowicz, Wrocław 2009, s. 163.

${ }^{16}$ Zob. A. Matan, Policja administracyjna jako funkcja administracji publicznej, [w:] Nauka administracji wobec wyzwań wspótczesnego państwa prawa. Międzynarodowa konferencja naukowa, Cisna 2-4 czerwca 2002 r., red. J. Łukaszewicz, Rzeszów 2002, s. 355-356. Jak zauważa Z. Leoński, policję administracyjną mogą spełniać organy „cywilne”, do których w szczególności zalicza różnego rodzaju inspekcje i nadzory (w tym organy nadzoru budowlanego). Z. Leoński, Zarys prawa administracyjnego, Warszawa 2004, s. 466.

${ }^{17}$ M. Janik, Policja sanitarna, Warszawa 2012, s. 58.

${ }^{18}$ Zob. E. Kulesza, J. Słoniński, Prawo budowlane, Warszawa-Poznań 1978, s. 8-9. 
Przez bezpieczeństwo publiczne należy rozumieć stan, w którym ogółowi obywateli indywidualnie nieoznaczonemu, żyjącemu w państwie i społeczeństwie, nie grozi żadne niebezpieczeństwo, i to niezależnie od tego, jakie byłoby jego źródło ${ }^{19}$. Bezpieczeństwo to ogół warunków i instytucji chroniących państwo i obywateli przed zjawiskami groźnymi dla ładu prawnego, a także ochrona ustroju przed zamachami na podstawowe instytucje $\mathrm{e}^{20}$. W literaturze pojęcie bezpieczeństwa jest różnie określane. Najczęściej jest rozumiane jako stan spokoju, pewności, zabezpieczenia, ochrony czy braku zagrożeńn ${ }^{21}$. Według M. Brzezińskiego bezpieczeństwo to stan, w którym członkowie wspólnoty państwowej nie odczuwają zagrożenia lub lęku ze strony organów państwa lub innych państw. To stan pewności i zabezpieczenia; stan wolności od niepokoju, zagrożenia, strachu, niebezpieczeństwa, ataku albo poczucia zagrożenia ze strony niestabilnego porządku; zapewnia swobodę działania, której nie towarzyszy poczucie zagrożenia $^{22}$. Bezpieczeństwo to uwypuklenie przeciwieństw (brak zagrożeń) lub podkreślenie pozytywnych stanów (spokoju, pewności, wolności) ${ }^{23}$. Inaczej ujmując, to stan braku zagrożenia dla dobra prawnego człowieka, który daje możliwość naturalnego działania jednostki w społeczeństwie, a w szczególności zachowanie życia, zdrowia, mienia oraz autonomię korzystania z wszystkich przypadających jednostce praw podmiotowych, które są zapewnione w konstytucji i innych przepisach prawa, nad którego realizowaniem czuwają organy państwowe zaopatrzone we właściwe kompetencje ${ }^{24}$.

Jak zauważa S. Pikulski, bezpieczeństwo jest najwyższą wartością społeczną, która warunkuje bezpieczeństwo życia, zdrowia obywateli, a także gwarantuje nienaruszalność ich mienia. Definiuje on bezpieczeństwo jako pewien pożądany stan rzeczy, gwarantujący niezakłócone funkcjonowanie urządzeń publicznych w państwie oraz bezpieczeństwo życia, zdrowia i mienia obywateli ${ }^{25}$. Zdaniem K. Sienkiewicz-Małyjurek bezpieczeństwo jest ciągłym procesem społecznym, w ramach którego podmioty działające starają się doskonalić mechanizmy zapewniające poczucie bezpieczeństwa. Jak zauważa, bezpieczeństwo podlega prawom ruchu systemów społecznych i jako takie powinno być ujmowane w sposób

${ }^{19}$ E. Ura, Pojęcie ochrony bezpieczeństwa i porządku publicznego, „Państwo i Prawo” 1974, z. 2 , s. 80 .

${ }^{20}$ J. Bralczyk, Stownik 100 tysięcy potrzebnych stów, Warszawa 2005, s. 448.

${ }^{21}$ R. Zięba, Instytucjonalizacja bezpieczeństwa europejskiego, Warszawa 2007, s. 27.

${ }^{22}$ S. Sulowski, M. Brzeziński, Bezpieczeństwo wewnętrzne państwa, Warszawa 2009, s. 22.

${ }^{23}$ M. Lisiecki, Zarządzanie bezpieczeństwem publicznym, Warszawa 2011, s. 21.

${ }^{24}$ W. Hermaliński, Bezpieczeństwo publiczne a prawo jednostki do prywatności, „Palestra” 2013, nr 1-2, s. 17.

${ }^{25}$ S. Pikulski, Podstawowe zagadnienia bezpieczeństwa publicznego, [w:] Prawne i administracyjne zagadnienia bezpieczeństwa osób i porządku publicznego w okresie transformacji ustrojowo-gospodarczej, red. W. Bednarek, S. Pikulski, Olsztyn 2000, s. 101. 
dynamiczny ${ }^{26}$. Mając na uwadze ten pogląd, można stwierdzić, że bezpieczeństwo to proces, w którym stan bezpieczeństwa i jego organizacja podlegają dynamicznym przekształceniom stosownie do naturalnych zmian uwarunkowań bezpieczeństwa ${ }^{27}$.

Powyżej przedstawione określenia dotyczące pojęcia bezpieczeństwa wskazują, że jest to pojęcie bardzo obszerne i niejednoznacznie określone w literaturze naukowej. Wymienić tutaj można bezpieczeństwo publiczne, bezpieczeństwo jednostki czy bezpieczeństwo państwa ${ }^{28}$.

Problematyka bezpieczeństwa dotyczy szerokiego obszaru dziedzin życia. Szczególnie jest to zauważalne w przepisach prawa budowlanego ukierunkowanych na zapewnienie bezpieczeństwa obiektów budowlanych oraz zaspokojenie potrzeb użytkowych obiektów na określonym poziomie. O bezpieczeństwie obiektu budowlanego decyduje w zasadniczym zakresie jego właściwe użytkowanie, tzn. użytkowanie zgodne z jego przeznaczeniem i wymaganiami ochrony środowiska, a także utrzymywanie obiektu w należytym stanie technicznym i estetycznym, niedopuszczające do nadmiernego pogorszenia właściwości użytkowych i sprawności technicznej obiektu. Do podstawowych działań policji budowlanej można zaliczyć: 1) procedury dotyczące rozpoczynania, prowadzenia i zakończenia robót budowlanych, a także użytkowania obiektów budowlanych, 2) obowiązki organów administracji architektoniczno-budowlanej i nadzoru budowlanego w zakresie robót i obiektów budowlanych, 3) zasady postępowania w sprawie katastrofy budowlanej, w szczególności związane z ustaleniem przyczyn i okoliczności jej zaistnienia, 4) sankcje karne za naruszanie przepisów prawa budowlanego, odpowiedzialność zawodową w budownictwie i zasady prowadzenia postępowania w sprawach tej odpowiedzialności wobec osób wykonujących samodzielne funkcje techniczne.

Ochrona policyjna polega zatem na odwracaniu potencjalnych niebezpieczeństw zagrażających państwu jako takiemu, większej lub mniejszej grupie obywateli i poszczególnym jednostkom ${ }^{29}$. Ochrona bezpieczeństwa jest jednym z celów państwa ${ }^{30}$. Zdaniem B. Banaszaka bezpieczeństwo państwa należy utożsa-

${ }^{26}$ K. Sienkiewicz-Małyjurek, Z. Niczyporuk, Bezpieczeństwo publiczne - zakres problematy$k i$, Gliwice 2010, s. 15-16.

${ }^{27}$ M. Leszczyński, Istota bezpieczeństwa w ujęciu Strategii Bezpieczeństwa Narodowego RP, [w:] Państwo i prawo wobec współczesnych wyzwań. Problemy administracji, zarzadzania i ekonomii. Ksiega jubileuszowa Profesora Jerzego Jaskierni, red. R.M. Czarny, K. Spryczak, Torun 2012, s. 195.

${ }^{28}$ T. Szubrych, Współczesne aspekty bezpieczeństwa państwa, „Zeszyty Naukowe Akademii Marynarki Wojennej” 2006, nr 4, s. 88.

${ }^{29}$ W. Kawka, Policja w ujęciu historycznym i wspótczesnym, Wilno 1939, s. 46.

${ }^{30}$ D. Gatner, Policja administracyjna (studium z teorii myśli administracyjnej), „Organizacja Metody - Technika" 1988, nr 8-9, s. 28. 
miać $\mathrm{z}$ bezpieczeństwem obywateli określonym w art. 5 Konstytucji $\mathrm{RP}^{31}$, mówiącym, że „Rzeczpospolita Polska strzeże niepodległości i nienaruszalności swojego terytorium, zapewnia wolności i prawa człowieka i obywatela oraz bezpieczeństwo obywateli, strzeże dziedzictwa narodowego oraz zapewnia ochronę środowiska, kierując się zasadą zrównoważonego rozwoju". Na gruncie prawa budowlanego kwestie bezpieczeństwa zawiera art. 5 pr. bud., który wymienia podstawowe wymogi dla projektowanych, budowanych i użytkowanych obiektów budowlanych. Jak widać, bezpieczeństwo dotyczy również szeroko rozumianego procesu budowlanego obejmującego wszystkie etapy: od projektowania po rozbiórkę obiektu budowlanego. Ponadto termin ten jest bardzo zbliżony do pojęcia porządku publicznego, który oznacza stan braku zagrożenia dla działania państwa i realizacji jego interesów ${ }^{32}$. Zdaniem M. Kotulskiego pojęcia bezpieczeństwa i porządku publicznego nie można jednoznacznie i raz na zawsze ustalić, ponieważ są one uzależnione od wielu czynników. Na ustalenie ich zakresu znaczeniowego mają wpływ wyznaczane standardy zachowań w danej grupie społecznej, zmieniające się warunki życia, a wraz z nimi zmieniające się poglądy społeczne i przepisy prawne ${ }^{33}$.

Przez porządek publiczny rozumie się system urządzeń prawno-publicznych i stosunków społecznych powstających i kształtujących się w miejscach publicznych oraz w miejscach niepublicznych, którego celem i zadaniem jest w szczególności ochrona życia ${ }^{34}$, zdrowia, mienia i zapewnienie normalnej działalności instytucji oraz eliminowanie różnego rodzaju uciążliwości ze strony niebezpiecznych lub niedogodnych dla społeczeństwa jednostek ${ }^{35}$. Można więc przyjąć, że porządek publiczny to pewien element bezpieczeństwa publicznego, którego zewnętrznym przejawem jest przestrzeganie norm prawnych, moralnych, obyczajowych i religijnych, skutkiem czego jest harmonizacja życia poszczególnych jednostek i społeczności ludzkich ${ }^{36}$. W ten sposób wyrażany przez normy akceptowane społecznie porządek publiczny dotyczy bezkonfliktowego i niezachwia-

\footnotetext{
${ }^{31}$ B. Banaszak, Konstytucja Rzeczypospolitej Polskiej. Komentarz, Warszawa 2009, s. 52.

${ }^{32} \mathrm{~J}$. Zając, Bezpieczeństwo państwa, [w:] Bezpieczeństwo państwa, red. A. Wojtaszczyk, A. Materska-Sosnowska, Warszawa 2009, s. 18.

${ }^{33}$ M. Kotulski, Samorząd terytorialny wobec zapewnienia porządku i bezpieczeństwa publicznego, [w:] Prawne i administracyjne zagadnienia bezpieczeństwa ..., s. 311.

${ }^{34}$ Życie i zdrowie są wartościami kluczowymi w polskim systemie prawa. Zdaniem Trybunału Konstytucyjnego życie ludzkie stanowi wartość o randze najwyższej w naszej cywilizacji i kulturze prawnej. Zob. wyrok TK z dnia 30 września 2008 r., K 44/07, LEX nr 441911.

${ }^{35}$ S. Bolesta, Pojęcie porzadku publicznego w prawie administracyjnym, „Studia Prawnicze” 1983, nr 1, s. 256.

${ }^{36}$ E. Ura, S. Pieprzny, T. Pado, Pojęcie bezpieczeństwa publicznego w prawie administracyjnym, [w:] Koncepcja systemu prawa administracyjnego..., s. 166.
} 
nego działania jednostek w społeczeństwie ${ }^{37}$. Spełnienie przez władze publiczne zadań z zakresu porządku publicznego może być rozumiane także jako wymóg eliminacji naruszania reguł dotyczących korzystania przez obywateli z miejsc publicznych $^{38}$. Zatem, dokonując próby określenia pojęcia porządku publicznego, należy zauważyć, że jest to stan faktyczny wewnątrz państwa, regulowany normami prawnymi i pozaprawnymi (obyczajowymi, moralnymi, religijnymi, zasadami współżycia społecznego itp.), których przestrzeganie umożliwia normalne współżycie jednostek w organizacji państwowej, w określonym miejscu i czasie ${ }^{39}$.

Z powyższego przeglądu widać, że bezpieczeństwo publiczne i porządek publiczny są pojęciami, które wielokrotnie występują w przepisach prawa łącznie, co jest wskazówką, że treści tych pojęć zachodzą na siebie w pewnym obszarze. Jednakże nie są one tożsame, ponieważ dotyczą dwóch różnych sfer życia społecznego, tzn. chronią pewne dobra i pewne stany. Określenie wzajemnych relacji i zależności pomiędzy tymi stanami nie jest łatwe. Bardzo trudno wskazać granice, gdzie kończy się bezpieczeństwo, a zaczyna się porządek publiczny. Oddzielenie bezpieczeństwa od porządku publicznego wydaje się jednak uzasadnione ze względu na wspomniany dwoisty przedmiot ochrony. Bezpieczeństwo publiczne to pewien stan pozytywny, odnoszący się do ochrony życia i zdrowia ludzi, ich mienia i środowiska. Natomiast porządek publiczny to pewien pożądany stan (bezpieczeństwa, porządku, spokoju publicznego), który ma umożliwiać normalny rozwój życia społecznego, polegający na przestrzeganiu obowiązującego porządku prawnego ${ }^{40}$.

W literaturze spotyka się również określenie spokoju publicznego. Według W. Kawki spokój publiczny można nazwać ogólnym spokojem w państwie, który stanowi fundament bezpieczeństwa publicznego i porządku publicznego ${ }^{41}$. Jednakże ścisły związek i brak legalnych definicji tych pojęć nakazuje uznać, że prawodawca, używając ich, traktował je jako synonimy ${ }^{42}$. Można wobec tego przyjąć, że pojęcie spokoju publicznego nie wnosi żadnego nowego elementu do rozważań nad bezpieczeństwem i porządkiem publicznym ${ }^{43}$. Wszystkie te pojęcia zawierają w sobie bogate treści i pełnią rozmaite, komplementarne w stosunku do siebie,

${ }^{37}$ J. Zając op. cit., s. 18.

${ }^{38}$ Ustrój i organizacja Policji w Polsce oraz jej funkcje i zadania w ochronie bezpieczeństwa i porzadku (reforma Policji, część I), red. J. Widacki, Warszawa-Kraków 1998, s. 15.

39 J. Filaber, Pojęcie porządku publicznego w nauce prawa administracyjnego, [w:] Bezpieczeństwo wewnętrzne we współczesnym państwie, red. E. Ura, K. Rajchel, M. Pomykała, S. Pieprzny, Rzeszów 2008, s. 34.

${ }^{40}$ A. Osierda, Prawne aspekty pojęcia bezpieczeństwa publicznego i porządku publicznego, „Studia Iuridica Lublinensia” 2014, t. 23, DOI: http://dx.doi.org/10.17951/sil.2014.23.0.89, s. 99.

${ }^{41}$ W. Kawka, op. cit., s. 80.

${ }^{42}$ S. Pieprzny, Administracja bezpieczeństwa i porzadku publicznego, Rzeszów 2008, s. 17.

${ }^{43}$ Tak: E. Ura, Prawne formy i metody działania policji, „Annales UMCS. Sectio G” 1995, t. 42 , s. 143 . 
role $\mathrm{w}$ dziedzinie ochrony przed bezprawnymi zamachami naruszającymi określone dobra, takie jak życie, zdrowie czy mienie ${ }^{44}$.

Trzecią kategorią wartości chronioną przez policję budowlaną jest ład architektoniczno-przestrzenny ${ }^{45}$. Ład architektoniczny to mechanizm obejmujący zespół procesów związanych z używaniem i utrzymaniem modeli architektonicznych $^{46}$. Natomiast ład przestrzenny w świetle art. 2 pkt 1 ustawy z dnia 27 marca 2003 r. o planowaniu i zagospodarowaniu przestrzennym ${ }^{47}$ to ,takie ukształtowanie przestrzeni, które tworzy harmonijną całość oraz uwzględnia w uporządkowanych relacjach wszelkie uwarunkowania i wymagania funkcjonalne, społeczno-gospodarcze, środowiskowe, kulturowe oraz kompozycyjno-estetyczne". Mimo że definicja legalna ładu przestrzennego zachowuje moc obowiązującą tylko na potrzeby tej jednej ustawy, to ze względu na bliskość gospodarki przestrzennej i budownictwa rozumienie tego pojęcia można przenieść na potrzeby analizy prawa budowlanego $0^{48}$. Ład przestrzenny odwołuje się do ocen pozaprawnych i jako kategoria musi być ujmowany z uwzględnieniem wiedzy wypracowanej nie tylko w naukach prawnych, ale także w innych dyscyplinach wiedzy (np. urbanistyce, architekturze czy gospodarce przestrzennej) ${ }^{49}$. Do pojęć składających się na ustawową definicję ładu przestrzennego i mogących budzić wątpliwości dotyczące ich rozumienia można zaliczyć np. takie terminy, jak: harmonijna całość, uporządkowane relacje, wszelkie uwarunkowania i wymagania kompozycyjno-estetyczne. Nie podlegają one sprecyzowaniu, a przy ich stosowaniu trzeba kierować się ogólną wiedzą z zakresu kształtowania polityki przestrzennej ${ }^{50}$. Dlatego należy w tym przypadku zachować szczególną ostrożność przy posługiwaniu się tymi terminami ${ }^{51}$. Ochrona ładu architektoniczno-przestrzennego wymaga bowiem interpretacji w oparciu o wiedzę pozaprawną dla każdego konkretnego przypadku. Oznacza to, że wszelkie działania, których celem jest kształtowanie przestrzeni, powinny uwzględniać wskazane wartości przy zastrzeżeniu, że działania te zmierzają do takiego ukształtowania przestrzeni i architektury, które będzie można zakwalifikować jako wspomniany ład ${ }^{52}$.

${ }^{44}$ M. Janik, op. cit., s. 66.

${ }^{45}$ Zob. wyrok TK z dnia 20 kwietnia 2011 r., Kp 7/09, OTK-A ZU 2011, nr 3, poz. 26.

${ }^{46}$ A. Sobczak, Struktura tadu architektonicznego, www.slideshare.net/andrzej_sobczak/0pojecie-laduarchitektonicznego [dostęp: 10.10.2017].

${ }^{47}$ T.j. Dz.U. z 2016 r., poz. 778.

${ }^{48}$ D. Sypniewski, Nadzór nad procesem budowlanym, Warszawa 2011, s. 66.

${ }^{49}$ M. Woźniak, Tradycja prawna budowania ładu przestrzennego w Polsce, „Przegląd Legislacyjny" 2011, nr 2-4, s. 88.

${ }^{50} \mathrm{H}$. Nowicki, [w:] Aspekty prawne planowania $i$ zagospodarowania przestrzennego, red. W. Szwajdler, Warszawa 2013.

${ }^{51}$ W. Szwajdler, T. Bąkowski, Proces inwestycyjno-budowlany. Zagadnienia prawne, Toruń 2004, s. 29.

${ }^{52}$ K. Małysa-Sulińska, Normy ksztattujące ład przestrzenny, Warszawa 2008, s. 25. 
Ochrona takich wartości, jak bezpieczeństwo, porządek publiczny i ład architektoniczno-przestrzenny, jest podstawowym celem regulacji prawnej określającej zadania policji budowlanej. Zdaniem T. Sienkiewicza warunkiem skuteczności ochrony tych wartości jest poprawne skonstruowanie ustroju organu administracji, który ma dokonywać czynności policyjnych. Przesłanki skuteczności policji budowlanej mogą dotyczyć nie tylko prawa, ale też czynnika ludzkiego - jego profesjonalizmu oraz etyki ${ }^{53}$.

Funkcja policji budowlanej jako służby publicznej stanowi warstwę prawa administracyjnego, której nie można pomijać przy próbie określania prawa budowlanego. Podstawowe wartości, jak bezpieczeństwo, porządek i ład architektoniczno-przestrzenny, stanowią centralną pozycję wśród artykułowanych przez prawodawcę wartości zawartych w prawie budowlanym. Cechą policji budowlanej jest przede wszystkim zapobieganie wszelkim niebezpieczeństwom dla życia i zdrowia ludzi oraz porządku publicznego i ładu, które mogłyby wynikać z nieodpowiedniego wykonywania robót budowlanych i stanu obiektów budowlanych. W tym celu policja budowlana powinna stosować niezbędne środki konieczne polegające na podejmowaniu działań określonych na podstawie i w granicach prawa, zgodnie z wymogami demokratycznego państwa prawa. Środki te polegają na wykonaniu przepisów obowiązującego prawa, które wiążą się z wydawaniem aktów indywidualnych ex ante (w celu zapobieżenia naruszeniom wartości chronionych) oraz ex post (w celu przywrócenia poprzedniego stanu). W rzeczywistości działania te są traktowane jako nadzór policyjny.

\section{BIBLIOGRAFIA}

Banaszak B., Konstytucja Rzeczypospolitej Polskiej. Komentarz, Warszawa 2009.

Boć J., [w:] Prawo administracyjne, red. J. Boć, Wrocław 2004.

Bolesta S., Pojęcie porządku publicznego w prawie administracyjnym, „Studia Prawnicze” 1983, nr 1. Bralczyk J., Słownik 100 tysięcy potrzebnych słów, Warszawa 2005.

Chajbowicz A., O podmiotowym znaczeniu pojęcia policja administracyjna, [w:] Nowe problemy badawcze w teorii prawa administracyjnego, red. J. Boć, A. Chajbowicz, Wrocław 2009.

Dobkowski J., Policja administracyjna. Zagadnienia doktrynalno-instytucjonalne, „Samorząd Terytorialny" 2004, nr 7-8.

Filaber J., Pojęcie porządku publicznego w nauce prawa administracyjnego, [w:] Bezpieczeństwo wewnętrzne we współczesnym państwie, red. E. Ura, K. Rajchel, M. Pomykała, S. Pieprzny, Rzeszów 2008.

Fundowicz S., Aksjologia prawa administracyjnego, [w:] Koncepcja systemu prawa administracyjnego. Zjazd Katedr Prawa Administracyjnego i Postępowania Administracyjnego, Zakopane 24-27 września 2006 r., red. J. Zimmermann, Warszawa 2007.

${ }^{53}$ T. Sienkiewicz, Przesłanki skuteczności policji administracyjnej, [w:] Ius et Historia. Księga pamiatkowa dedykowana Profesorowi Jerzemu Markiewiczowi, red. T. Guz, W. Bednarek, M.R. Pałubska, Lublin 2011, s. 572-573. 
Gatner D., Policja administracyjna (studium z teorii myśli administracyjnej), „Organizacja Metody - Technika" 1988, nr 8-9.

Hauser R., Niewiadomski Z., Konstytucyjne aspekty regulacji procesu inwestycyjno-budowlanego, „Państwo i Prawo” 2015, z. 6.

Hermaliński W., Bezpieczeństwo publiczne a prawo jednostki do prywatności, „Palestra” 2013, nr $1-2$.

Jakimowicz W., Konstrukcja i istota wolnościowego prawa do zabudowy, „Samorząd Terytorialny” 2005, $\mathrm{nr} 6$.

Janik M., Policja sanitarna, Warszawa 2012.

Kalinka K., Relacje grup nacisku z administracja publiczna jako swoista wartość w prawie administracyjnym, [w:] Wartości w prawie administracyjnym. V Krakowsko-Wrocławskie Spotkanie Naukowe Administratywistów, red. J. Zimmermann, Warszawa 2015.

Kawka W., Policja w ujęciu historycznym $i$ współczesnym, Wilno 1939.

Konstytucja Rzeczypospolitej Polskiej z dnia 2 kwietnia 1997 r. (Dz.U. nr 78, poz. 483 ze sprost. i późn. zm.).

Kotulski M., Samorzad terytorialny wobec zapewnienia porzadku i bezpieczeństwa publicznego, [w:] Prawne i administracyjne zagadnienia bezpieczeństwa osób i porzadku publicznego w okresie transformacji ustrojowo-gospodarczej, red. W. Bednarek, S. Pikulski, Olsztyn 2000.

Kulesza E., Słoniński J., Prawo budowlane, Warszawa-Poznań 1978.

Leoński Z., Materialne prawo administracyjne, Warszawa 2005.

Leoński Z., Zarys prawa administracyjnego, Warszawa 2004.

Leoński Z., Zasada wolności budowlanej i jej administracyjnoprawne ograniczenia [w:] Kierunki rozwoju prawa administracyjnego. Podstawowe zagadnienia prawa budowlanego i planowania przestrzennego. Dziesiąte niemiecko-polskie kolokwium prawników administratywistów. Poznań 8-12 września 1997 r. Referaty i głosy w dyskusji, red. H. Bauer, R. Hendler, P.M. Huber, B. Popowska, T. Rabska, M. Szewczyk, Poznań 1999.

Leoński Z., Zasada wolności budowlanej i jej administracyjnoprawne ograniczenia, [w:] Rola materialnego prawa administracyjnego a ochrona praw jednostki, red. Z. Leoński, Poznań 1998.

Leoński Z., Szewczyk M., Kruś M., Prawo zagospodarowania przestrzeni, Warszawa 2012.

Leszczyński M., Istota bezpieczeństwa w ujęciu Strategii Bezpieczeństwa Narodowego RP, [w:] Państwo i prawo wobec współczesnych wyzwań. Problemy administracji, zarzadzania i ekonomii. Księga jubileuszowa Profesora Jerzego Jaskierni, red. R.M. Czarny, K. Spryczak, Toruń 2012.

Lisiecki M., Zarządzanie bezpieczeństwem publicznym, Warszawa 2011.

Małysa-Sulińska K., Normy ksztattujące ład przestrzenny, Warszawa 2008.

Matan A., Policja administracyjna jako funkcja administracji publicznej, [w:] Nauka administracji wobec wyzwań wspótczesnego państwa prawa. Międzynarodowa konferencja naukowa, Cisna 2-4 czerwca 2002 r., red. J. Łukaszewicz, Rzeszów 2002.

Miemiec M., Wartości jako przedmiot ochrony w policyjnym prawie administracyjnym, [w:] Wartości w prawie administracyjnym. V Krakowsko-Wrocławskie Spotkanie Naukowe Administratywistów, red. J. Zimmermann, Warszawa 2015.

Nowicki H., [w:] Aspekty prawne planowania i zagospodarowania przestrzennego, red. W. Szwajdler, Warszawa 2013.

Osierda A., Prawne aspekty pojęcia bezpieczeństwa publicznego i porządku publicznego, „Studia Iuridica Lublinensia" 2014, t. 23, DOI: http://dx.doi.org/10.17951/sil.2014.23.0.89.

Pieprzny S., Administracja bezpieczeństwa i porzadku publicznego, Rzeszów 2008.

Pikulski S., Podstawowe zagadnienia bezpieczeństwa publicznego, [w:] Prawne i administracyjne zagadnienia bezpieczeństwa osób i porzadku publicznego $w$ okresie transformacji ustrojowo-gospodarczej, red. W. Bednarek, S. Pikulski, Olsztyn 2000. 
Sienkiewicz T., Przestanki skuteczności policji administracyjnej, [w:] Ius et Historia. Księga pamiatkowa dedykowana Profesorowi Jerzemu Markiewiczowi, red. T. Guz, W. Bednarek, M.R. Pałubska, Lublin 2011.

Sienkiewicz-Małyjurek K., Niczyporuk Z., Bezpieczeństwo publiczne - zakres problematyki, Gliwice 2010.

Sobczak A., Struktura ładu architektonicznego, www.slideshare.net/andrzej_sobczak/0-pojecieladuarchitektonicznego [dostęp: 10.10.2017].

Sulowski S., Brzeziński M., Bezpieczeństwo wewnętrzne państwa, Warszawa 2009.

Sypniewski D., Nadzór nad procesem budowlanym, Warszawa 2011.

Szubrych T., Wspótczesne aspekty bezpieczeństwa państwa, „Zeszyty Naukowe Akademii Marynarki Wojennej" 2006, nr 4.

Szwajdler W., Bąkowski T., Proces inwestycyjno-budowlany. Zagadnienia prawne, Toruń 2004.

Ura E., Pojęcie ochrony bezpieczeństwa i porządku publicznego, „Państwo i Prawo” 1974, z. 2.

Ura E., Prawne formy i metody działania policji, „Annales UMCS. Sectio G” 1995, t. 42.

Ura E., Pieprzny S., Pado T., Pojęcie bezpieczeństwa publicznego w prawie administracyjnym, [w:] Koncepcja systemu prawa administracyjnego. Zjazd Katedr Prawa Administracyjnego i Postępowania Administracyjnego, Zakopane 24-27 września 2006 r., red. J. Zimmermann, Warszawa 2007.

Ustawa z dnia 7 lipca 1994 r. - Prawo budowlane (t.j. Dz.U. z 2016 r., poz. 290).

Ustawa z dnia 27 marca 2003 r. o planowaniu i zagospodarowaniu przestrzennym (t.j. Dz.U. z 2016 r., poz. 778).

Ustrój i organizacja Policji w Polsce oraz jej funkcje i zadania w ochronie bezpieczeństwa i porzadku (reforma Policji, część I), red. J. Widacki, Warszawa-Kraków 1998.

Woźniak M., Tradycja prawna budowania ładu przestrzennego w Polsce, „Przegląd Legislacyjny” 2011, nr 2-4.

Wyrok TK z dnia 30 września 2008 r., K 44/07, LEX nr 441911.

Wyrok TK z dnia 20 kwietnia 2011 r., Kp 7/09, OTK-A ZU 2011, nr 3, poz. 26.

Wyrzykowski M., Legislacja-demokratyczne państwo prawa-radykalne reformy polityczne i gospodarcze, [w:] Tworzenie prawa w demokratycznym państwie prawnym, red. H. Suchocka, Warszawa 1992.

Zając J., Bezpieczeństwo państwa, [w:] Bezpieczeństwo państwa, red. A. Wojtaszczyk, A. Materska-Sosnowska, Warszawa 2009.

Zamyślewska-Gorząch K., Wolność budowlana i jej prawne ograniczenia, „Samorząd Terytorialny” 2005, nr 10.

Zięba R., Instytucjonalizacja bezpieczeństwa europejskiego, Warszawa 2007.

\section{SUMMARY}

This paper concerns the protection of fundamental values such as security, as well as public, architectural, and spatial order. These values can already be seen through the prism of restrictions on freedom of the construction. The protection of these values is particularly valuable for society and is one of the characteristics attributed to the construction police. Important role in this area is entrusted to the construction police, an institution associated with identifying and preventing threats affecting the overall safety and order in the construction industry.

Keywords: construction law; construction police; security and public order; architectural and spatial order 